\title{
Effect of Fair Value Accounting on Assets of Consumer Goods Firms in Nigeria
}

\author{
Ubesie Madubuko Cyril ${ }^{1}$, Akparhuere Godwin Oghenekohwo ${ }^{1}$, Mba Chris Chukwuemeka ${ }^{2}$ \\ ${ }^{1}$ Department of Accountancy, Enugu State University of Science and Technology (ESUT), Enugu, Nigeria \\ ${ }^{2}$ Department of Marketing, Enugu State University of Science and Technology (ESUT), Enugu, Nigeria
}

\section{Email address:}

ubesiemadubuko@yahoo.com (U. M. Cyril)

\section{To cite this article:}

Ubesie Madubuko Cyril, Akparhuere Godwin Oghenekohwo, Mba Chris Chukwuemeka. Effect of Fair Value Accounting on Assets of Consumer Goods Firms in Nigeria. Science Journal of Business and Management. Vol. 7, No. 6, 2019, pp. 150-158.

doi: $10.11648 / j . s j b m .20190706 .13$

Received: October 10, 2019; Accepted: November 28, 2019; Published: December 13, 2019

\begin{abstract}
Fair value of a firm's asset is one of the determinants of its net-worth and marketability. It is a rational and unbiased estimate of the potential market price of a good (commodity), stock, service or asset of a firm. The main objective of the study is to determine the effect of fair value accounting on assets of consumer goods manufacturing companies in Nigeria. The study adopted ex-post facto research design and data were sourced from three selected companies through purposive sampling technique. Analysis was carried out on ten years pooled data on total assets (the dependent variable), fair value (proxy by share value), market value (proxy by Net Assets), and depreciation value. The findings show that fair value has significant effect on assets of consumer goods firms in Nigeria. The study recommends that management of consumer goods companies should consolidate on improvement of fair value of firms through their assets management and appropriate policies, adopt the best practices that would raise the share prices and maintain higher book values of the firms, and use depreciation as a source of replacement of old assets thereby stabilizing the Net worth of the firms.
\end{abstract}

Keywords: Fair Value, Assets, Consumer Goods Firms

\section{Introduction}

\section{A. Background of the Study}

Fair value of a firm's asset is one of the determinants of its net-worth and marketability. It is a rational and unbiased estimate of the potential market price of a good (commodity), stock, service or asset of a firm. According to Ubesie (2018) "fair value is a rational and unbiased estimate of the potential market price of a good (commodity), service or asset. This means there must also be an unfair value. Fair value has to do with element of fairness" [1]. To that extent, fair value takes into cognizance some objective factors such as acquisition cost, production cost, distribution cost, replacement or cost of substitution.

Fair value is a sales price agreed to by a willing buyer and seller, assuming both parties entered the transaction freely. Furthermore, it represents the value of a company's assets and liabilities when a subsidiary company's financial statements are consolidated with a parent company. Others look at fair value from the point of view of stock value. In this regard, fair value becomes the price that a security analyst or investor places on a stock based on a common stock valuation known as Net Asset valuation. The totality of the whole thing is that fair value accounting uses current market value as the basis for recognizing certain assets and liabilities. Therefore, fair value is an estimated price at which an asset can be sold or a liability is settled in an orderly transaction.

The valuation of market price of assets takes a good assessment of the changes in market situation, the competitive prices and the historical changes in the assets of a firm. The change in price of asset is a traditional thing that financial analysts have continued to trail to keep up with market price. Investors also want to have a fore-knowledge of what the market looks like and keep track with the decision to put their money into guided uses. Prices valuation is not used for its sake but for investors to determine how efficiently and effectively finance or capital can be properly put into use.

B. Statement of the Problem 
The use of asset value in the analysis of firm's value is relatively common among many researchers in Nigeria. However, not many researchers in the manufacturing sector have been involved in extensive study of the subject matter as it relates to consumer goods firms in Nigeria. This is what this study is out to accomplish by examining the effect of fair value accounting on assets of consumer goods manufacturing firms in Nigeria.

C. Objectives of the Study

The main objective of the study is to ascertain the effect of fair value accounting on assets of consumer goods firms in Nigeria while the specific objectives are to:

i. Determine the effect of fair value on assets of consumer goods firms in Nigeria.

ii. Appraise the effect of market value on assets of consumer goods firms in Nigeria.

iii. Verify the effect of liability on assets of consumer goods firms in Nigeria.

D. Research Questions

The following research questions are pertinent in finding appropriate solutions to the specific questions in this study.

i. What effect does fair value have on assets of consumer goods companies in Nigeria?

ii. What effect does market value have on assets of consumer goods companies in Nigeria?

iii. What effect does depreciation have on assets of consumer goods companies in Nigeria?

E. Research Hypotheses

The study is guided by the following hypotheses:

$\mathrm{H}_{01}$ : Fair value does not have significant effect on assets of consumer goods companies in Nigeria.

$\mathrm{H}_{02}$ : Market value does not have significant effect on assets of consumer goods companies in Nigeria.

$\mathrm{H}_{03}$ : Depreciation does not have significant effect on assets of consumer goods companies in Nigeria.

\subsection{Fair Value Accounting}

Many authorities have defined fair value accounting in different ways and from different perspectives. Each definition was structured along some conceptual understanding and practices of the various bodies or organizations being referred to by the authors.

Accounting Tools (2018) defines fair value accounting as that "accounting that uses current market values as the basis for recognizing certain assets and liabilities. Fair value is the estimated price at which an asset can be sold or a liability settled in an orderly transaction to a third party under current market conditions" [2].

Fair value is also referred to by the Business Dictionary as "a price paid by a buyer who knows the value of what he or she is buying, to a seller who also knows the value of what is being sold, i.e., neither is cheating the other." It is also the relationship between a firm's equity returns and any unexpected earnings announcements. A firm's stock price is related to information available to investors.

According to Corporate Finance Institute (CFI) "fair value refers to the actual value of an asset - a product, stock, or security - that is agreed upon by both the seller and the buyer. Fair value is applicable to a product that is sold or traded in the market where it belongs or in normal conditions - and not to one that is being liquidated. It is determined in order to come up with an amount or value that is fair to the buyer without putting the seller on the losing end."

Balogun (2015) also explains that fair value accounting is an approach to financial reporting whereby profits are measured by comparing revenue with the current replacement cost of the assets consumed in the earning process [3]. The logic of this approach lies in the concept of the going concern. It recognizes in the income statement, the cost which a going concern actually has to pay to replace its expiring assets.

\section{A. Market value}

Market value is the price at which an asset would trade in a competitive auction setting. Market value is often used interchangeably with open market value, fair value or fair market value, although these terms have distinct definitions in different standards, and may or may not differ in some circumstances.

According to Chen (2019) market value is the price an asset would fetch in the market place. It is also known as market capitalization of a publicly traded company that could be obtained by multiplying the number of its outstanding sharesby the current share price [4].

Market value is the highest price that a willing buyer will pay for a good or service and the lowest price at which a willing seller will sell it if both the buyer and seller have all the relevant information concerning the purchase and the good or service has been exposed to the market for a reasonable time. Market value is usually different than market price. The market value of a good or service is the price that would be paid for it in a fair market.

A market must meet certain requirements for it to be a fair market. These are the price-to-sales, price-to-earnings, enterprise value-to-EBITDA (earnings before interest, taxes, depreciation and amortization) and so on [4].

\section{B. Assets}

The assets of an organization are used in daily operations and business activities to create wealth and improve performance. These are classified into current and noncurrent assets. Current assets are easily converted to cash while non-current assets are not. Some even distinguish the two by the characteristics as in being tangible or not tangible for non-current and tangible for current assets.

Current assets include bank and cash balances, debtors and other receivables, prepayments and inventories, etc. Noncurrent assets are such things as land and buildings, vehicles, plant, machinery and equipment, and so on.

Non-current assets are subject to depreciation and this causes a reduction in their total value. The historical cost of non-current assets reduces with time but land actually appreciates with time subject to its location and demand for its use.

The difference between historical cost and market value forms part of this discussion and it helps to determine the 
subject matter of this study. The need for proper'fair value' estimation is something that should not be overstressed since it depends on the understanding of the workings historical costs and market value over a given time.

\section{Depreciation}

According to Kenton (2019) depreciation is an accounting method of allocating the cost of a tangible asset over its useful life and is used to account for declines in value [5]. Businesses depreciate long-term assets for both tax and accounting purposes. For tax purposes, businesses can deduct the cost of the tangible assets they purchase as business expenses; however, businesses must depreciate these assets according to IRS rules about how and when the company can take the deduction. Depreciation is the assigning or allocating of the cost of a plant asset (other than land) to expense in the accounting periods that are within the asset's useful life.

There are four main methods for determining cost allocation of assets throughout their period of use within a company. Depreciation methods refer to the necessity for businesses to determine the projected loss of value of certain assets over time or based on actual physical usage. This allows for an effective allocation of costs throughout the 'useful life' of the asset in the correct period.

The four main methods for determining depreciation include straight-line depreciation, reducing balance depreciation, Sum-of-the-year's-digits depreciation, and Units of Production Depreciation.

D. The Resource Based Theory

The study is guided by the Resource Based Theory propounded by Jay Barney in 1991 in his famous article "Firm Resources and sustained competitive advantage." The resource-based view is a managerial framework used to determine the strategic resources a firm can exploit to achieve sustainable competitive advantage among firms. According to Resource Based View proponents, it is much more feasible to exploit external opportunities using existing resources in a new way rather than trying to acquire new skills for each different opportunity. In RBV model, resources are given the major role in helping companies to achieve higher organizational performance. There are two types of resources namely, tangible and intangible resources.

The theory is adopted in this study because of its relevance and the leaning on firm fair value as a basis for valuing the assets and competiveness of a firm. This is the main thrust of the study and it is related to the value of the firm's assets and marketability or possession by would-be investors.

\subsection{Empirical Review}

Elfaki and Hammad (2015) examined the effect of the use of fair value on the quality of accounting information. The descriptive approach was used because it is reliable for survey enquiries [6]. The researcher used statistical package for social sciences (SPSS) in the data analysis. The most important results that have been reached was that fair value contributes to provide useful information to users of financial statements and helps them in decision-making. There was a positive relationship between the application of fair value and the appropriateness of accounting information in decisionmaking. And also there was a positive relationship between the application of fair value and reliability of accounting information. Which means reliability of users, in addition to the fair value was able to make a fair comparison, both at the enterprise level for a number of periods or with similar enterprises for the same period.

Barth (1993) examined disclosed fair values of investment securities that can be considered more reliable than previously-studied fair value disclosures [7]. Moreover, the sampled firms here belong to one industry, banking. The study also investigated the Barth et al. (1990) suggestion that fair value securities gains and losses are value-relevant. By examining how share prices reflect historical costs and fair values, evidence is provided on the measures' relevance and reliability. The analyses provide evidence on the two methods' incremental and relative explanatory power, and relative measurement error. The findings indicate that fair value estimates of investment securities provide significant explanatory power beyond that provided by historical costs. Strikingly, historical costs provide no significant explanatory power incremental to fair values. Using a measurement error model, investment securities' fair values are found to have less measurement error than historical costs vis-a-vis the amount reflected in share prices. The findings for securities gains and losses are different. The significance of any incremental explanatory power for fair values beyond historical costs depends on the specification of the estimating equation. In some specifications, fair value securities gains and losses have no significant incremental explanatory power, but historical costs always provide explanatory power incremental to fair values. The findings based on a measurement error model indicate that fair value securities gains and losses also have more measurement error than historical costs. Thus, although fair value estimates of investment securities appear reliable and relevant to investors in valuing bank equity, fair value securities gains and losses do not.

Akwu (2014) examined fair value measurement in determination of profitability of listed manufacturing firms in Nigeria [8]. The ex-post facto research design was adopted for this study. A cross sectional data from the financial reports of manufacturing companies quoted on the 1st tier security market of the Nigerian Stock Exchange for Pre-IFRS of 2011 and Post IFRS of 2012 periods were used. The dependent variable is profitability while the independent variables are depreciation, inventory and taxation. The five companies studied were those that have complied with IFRS and they include: Champion Breweries Plc, Guinness Breweries Plc, International Breweries Plc, Nigerian Breweries Plc and 7-up Bottling Company Plc. The simple least square regression technique, correlation coefficient, and t-statistic were analytical tool were use dusing Econometric Views (E-Views) statistical software. Depreciation has positive and significant impact on profitability using fair value measurement. Inventory has positive and significant effect on profitability under fair value measurement and 
historical cost convention. A positive and significant relationship exists between taxation and profitability using fair value and historical cost convention.

Ibrahim (2016) investigated the effect of earnings quality properties on share price of listed manufacturing firms in Nigeria [9]. The population of the study comprised all the 37 quoted manufacturing firms on the Nigeria Stock Exchange as at $31^{\text {st }}$ December 2013 on which filters were employed to arrive at an adjusted population of 20 firms for the period $2009-2013$ to examine the effect of earnings quality properties proxy by accruals quality, income smoothing, earnings variability, timeliness of earnings and earnings conservativism on share price of the firms. The result of the robust Ordinary Least Square (OLS) revealed that of the five earnings quality attributes used in the study, accruals quality and timeliness of earnings have significant inverse relationship with share price, while earnings variability has significant positive relationship with share price. The study further revealed that income smoothing and earnings conservativism have negative but insignificant association with share price of listed manufacturing.

Okolie (2014) investigated the influence that audit firm size exerts on the market value per share of companies in Nigeria [10]. The study was hinged on a population of 342 firms listed on the Nigerian Stock Exchange (NSE) and used multivariate analyses on archival data covering the period 2006-2011. The study found that audit firm size exerted significant relationship and significantly influenced market price per share of the sampled companies.

Alade (2018) investigated the effect of IFRS adoption on value relevance of accounting information of Nigerian listed firms [11]. The study adopted descriptive research design approach and purposive sampling technique was used to select from a population of 128 quoted companies. The result showed that IFRS adoption had positive and significant effect on value relevance of income statement and financial position accounting information from NSE.

Kip (2009) focused on the effect of fair value accounting on the earnings response coefficient [12]. The findings show that fair value accounting influences the earnings response coefficient. It implies that an increase in the earnings response coefficient was noticeable across almost all industries but it was especially large for the finance, insurance and real estate industry. It was also found that higher ERC would show more information to the investors and will be perceived as more persistent earnings. Additionally, the value relevance of accounting amounts under fair value accounting is higher than under historical cost accounting. This also showed that fair value accounting is very informative to investors.

Ezejiofor (2018) evaluated the extent to which value relevance of financial information in Nigerian manufacturing firms has improved after the implementation of International Financial Reporting Standards (IFRS) [13]. Specifically, the study intended to: Ascertain the extent the adoption of IFRS has significantly improved the book value per share of manufacturing companies in Nigeria; Determine the extent the adoption of IFRS has significantly improved the Earnings Per Share of manufacturing companies in Nigeria and Examine the extent the adoption of IFRS has significantly improved the cash flow of manufacturing companies in Nigeria. Ex-post facto research design was adopted for the study. A sample of 54 manufacturing companies was randomly selected from manufacturing companies quoted on the Nigerian Stock Exchange for the periods of 2008-2015. Data for the study were obtained from the annual reports and accounts of the sampled companies. Specifically, a modified price model for detecting value relevance of accounting data for two different periods was employed. Regression Analysis and Chow test statistical tools were used to analyze and validate the data with aid of SPSS version 20.0. The study found that the adoption of IFRS has improved the book value per share, market share price, Earnings per Share and cash flow of manufacturing companies in Nigeria. The implication of findings is that the value relevance of accounting information of manufacturing companies is more sensitive during Post-IFRS era than the Pre-IFRS era. The findings also imply that the book value per share, market price, earnings and cash flow have become informative to equity investors in determining the value of firms following IFRS adoption. The study recommends among other things that the accounting information for book value per share should be communicated to the investing public; and such information should be of high quality to avoid negative consequences on the part of investors.

Ugwunta and Ugwuanyi (2018) examined the evidence over the existence and magnitude of the assumed negative relation between accounting conservatism and firm performance in Nigeria. Data from the annual financial statements of firms under the consumer goods sectoral classification on the Nigerian Stock exchange was used. The hypotheses were tested using the accounting conservatism has a positive but non-significant effect on firm performance while assuming the fixed effects. Opposed to the assumed negative relation, findings from the study have suggested that accounting conservatism has a positive but non-significant effect on firm performance [14]. Therefore, it implies that firms in the Nigerian consumer goods sector do not practice accounting conservatism and hence produces low financial reporting quality. This is given the absence of accruals quality achieved when the reported information reported is credible and free of error and bias, intentional or otherwise. The study recommended that firms in Nigeria should be penalized if reported information is found to be incomplete and opaque not free of error and bias.

Balogun (2015) assessed fair value accounting method with a view to determining its effect on historical cost method of asset valuation in public limited companies [3]. Five petroleum companies were purposively selected from a population of twelve petroleum companies listed on the Nigeria Stock Exchange. Descriptive research design was adopted using secondary method of data collection. Data on price level changes (Price Index) of the assets of the companies under review were obtained from the National 
Bureau of Statistics as published by the Central Bank of Nigeria while data on Historical values were obtained from the published annual financial statements of the companies and fair values were determined using the price index. T-test statistical tool was used in determining and analysing whether there is significant difference in assets valued under fair value as against historical cost method. Findings show that there was significant difference between assets valued at fair value and historical cost method. Findings also show that price level changes was the principal factor responsible for the difference in asset valuation and that financial statements prepared under these methods produced different information for the users.

Okafor, Ogbuehi and Anene (2017) determined the effect of International Financial Reporting Standards (IFRS) adoption on value relevance of accounting information in Nigeria [15]. The study was an empirical analysis of the effect of IFRS adoption on value relevance of book value, earnings per share, and cash flow from operations in the consumer goods firms sector. Three hypotheses guided the study. The ex-post facto research design was used. The population is made up of 25 consumer goods firms listed in Nigerian Stock Exchange. A total of 12 firms were chosen purposively on the basis of availability of data among other considerations was used. The study covered the period of eight years (2008-2015). Secondary data was collected on annual basis from reports of firms and database of Capital Assets was used. Multiple regression analysis was used in analyzing the data with the aid of Statistical Package for Social Sciences (SPSS) Version 22. The study showed that IFRS adoption has an incremental effect on the value relevance of book value, earnings per share, and cash flow from operations, with earnings per share showing the highest increment.

\section{Method}

\subsection{Research Design}

The study adopted ex post facto research design whereby secondary data already in existence and devoid of manipulation and bias were obtained from annual reports and accounts of the firms under the study. With the use of purpose sampling technique, out of the 20 listed consumer goods firms were selected and used.

\subsection{Model Specification}

The following simple regression model was used for the data analysis.

$$
\mathrm{NW}=f(\mathrm{FV}, \mathrm{MV}, \mathrm{DEP})
$$

\subsection{Description of the Variables}

The variables in the model are explained as follows:

Assets - proxy by total assetofthe company

FV - Fair value (proxy by share capital value)

MV - Market value (proxy by net asset)

DEP - Depreciationof tangible assets

\subsection{Technique for Data Analysis}

The data were analyzed using SPSS v. 20.0. The method of analyses is electronic and the statistical tools contained include correlation ( $\mathrm{r}$ ), coefficient of determination (R), and f-test (ANOVA) for test of the hypotheses.

\section{Result}

\subsection{Presentation of Data}

Table 1. Aggregated Data of Nigerian Breweries, Cadbury and Dangote Cement plc.

\begin{tabular}{llll}
\hline Year & Assets N'000 & Share Value N'000 & Net Assets N'000 \\
\hline 2009 & $500,206,254$ & $10,832,111$ & $387,811,772$ \\
2010 & $565,088,558$ & $11,695,621$ & $438,938,979$ \\
2011 & $758,847,498$ & $13,081,561$ & $545,736,972$ \\
2012 & $942,931,980$ & $13,866,201$ & $591,875,382$ \\
2013 & $2,527,596,415$ & $27,956,794$ & $703,099,899$ \\
2014 & $1,341,937,955$ & $13,866,794$ & $827,35,627$ \\
2015 & $1,509,599,128$ & $13,423,909$ & $35,025,219$ \\
2016 & $1,898,596,866$ & $13,423,906$ & $894,815,762$ \\
2017 & $2,051,116,662$ & $13,423,906$ & $1,058,779,333$ \\
2018 & $2,136,496,174$ & $13,557,552$ & $1,107,325,437$ \\
\hline
\end{tabular}

Source: Compilation by the Researcher.

\subsection{Analysis of Data}

Table 2. Description of the variables of the aggregated data.

\begin{tabular}{|c|c|c|c|c|c|}
\hline \multicolumn{6}{|c|}{ Descriptive Statistics } \\
\hline & $\mathbf{N}$ & Minimum & Maximum & Mean & Std. Deviation \\
\hline ASSETS & 10 & 500206254 & 2527596415 & 1423241749.00 & 716715271.202 \\
\hline SHCAP & 10 & 10832111 & 27956794 & 14512835.50 & 4825607.221 \\
\hline
\end{tabular}




\begin{tabular}{llllll}
\hline Descriptive Statistics & & & & & \\
\hline & N & Minimum & Maximum & Mean & Std. Deviation \\
\hline NETAS & 10 & 387811772 & 1438328027 & 799441558.80 & 332708102.031 \\
DEPR & 10 & 15418627 & 82434739 & 51396813.20 & 25959794.601 \\
Valid N (listwise) & 10 & & & & \\
\hline
\end{tabular}

Table 2 is the descriptive statistics of the dependent variable (asset) and the independent variables (share capital, net assets and depreciation). Assets recorded the highest values in the table where the minimum recorded amount was $\mathrm{N} 500,206,254$ while the maximum in the distribution is $\mathrm{N} 2,527,596,415$. The assets also recorded the biggest standard deviation.

The variable with the least minimum and maximum is share capital being $\$ 10,832,111$ and $\$ 27,956,794$ respectively.

\subsubsection{Analysis on Objective One}

Restatement of the objective

$\mathrm{H}_{0}$ : Fair value accounting does not have significant effect on assets of consumer goods manufacturing firms in Nigeria.

Decision Rule: Accept $\mathrm{H}_{0}$ if $\mathrm{p}$-value $>0.05$, otherwise reject.

Table 3. Correlation between Fair Value and Assets of Consumer Goods Companies in Nigeria.

\begin{tabular}{lllll}
\hline Model Summary & & & & \\
\hline Model & R & R Square & Adjusted R Square & Std. Error of the Estimate \\
\hline 1 & $.642^{\mathrm{a}}$ & .413 & .339 & 582524402.998 \\
\hline
\end{tabular}

a. Predictors: (Constant), SHCAP.

The analysis reveals that at $\mathrm{r}=0.642$, there is a positive and high correlation between fair value and the assets of consumer goods companies in Nigeria. The coefficient of determination $\left(\mathrm{R}^{2}=0.413\right)$ indicates that fair value explained 41.3 percent of the changes in assets during the period.

Table 4. Analysis of variance between Fair value and Assets of Consumer Goods Companies.

\begin{tabular}{llllll}
\hline ANOVA $^{\text {a }}$ & & & & & \\
\hline Model & & Sum of Squares & df & Mean Square & p-value \\
\hline \multirow{4}{*}{1} & Regression & 1908449579061924350.000 & 1 & 1908449579061924350.000 & \\
& Residual & 2714677440707575300.000 & 8 & 339334680088446910.000 \\
& Total & 4623127019769499600.000 & 9 & & \\
\end{tabular}

a. Dependent Variable: ASSETS.

b. Predictors: (Constant), SHCAP.

The result of the analysis in table 4 shows that $p$-value $=$ 0.045 . Since $\mathrm{p}$-value $<0.05$, we reject $\mathrm{H}_{0}$ and accept the alternative hypothesis. We conclude that fair value accounting has significant effect on assets of a consumer goods company in Nigeria.

Table 5. Regression Analysis on Assets and Fair Value.

\begin{tabular}{|c|c|c|c|c|c|c|}
\hline \multicolumn{7}{|c|}{ Coefficients $^{\mathrm{a}}$} \\
\hline \multirow{2}{*}{ Model } & & \multicolumn{2}{|c|}{ Unstandardized Coefficients } & \multirow{2}{*}{$\begin{array}{l}\text { Standardized Coefficients } \\
\text { Beta }\end{array}$} & \multirow{2}{*}{$\mathbf{t}$} & \multirow{2}{*}{ p-value } \\
\hline & & B & Std. Error & & & \\
\hline \multirow{2}{*}{1} & (Constant) & 38338629.668 & 612338604.692 & & .063 & .952 \\
\hline & SHCAP & 95.426 & 40.238 & .642 & 2.372 & .045 \\
\hline
\end{tabular}

a. Dependent Variable: ASSETS.

The regression formula or model is thus represented as:

$$
\mathrm{ASSET}=38,338,629.668+95.426(\mathrm{SHCAP})+40.238
$$

This means that fair value accounting contributed a fixed annual total of about N38bn to assets of consumer goods companies in Nigeria over the period. The period also recorded a marginal increase of about 95.426 in the assets of the consumer goods companies in Nigeria.

\subsubsection{Analysis on Objective Two}

Restatement of the Objective

$\mathrm{H}_{0}$ : Market value accounting does not have significant effect on assets of consumer goods manufacturing firms in Nigeria

Decision Rule: Accept $\mathrm{H}_{0}$ if p-value $>0.05$, otherwise reject.

Table 6. Correlation of Net Assetsand Assets of Consumer Goods Companies in Nigeria.

\begin{tabular}{lllll}
\hline Model Summary & & & & \\
\hline Model & R & R Square & Adjusted R Square & Std. Error of the Estimate \\
\hline 1 & $.759^{\mathrm{a}}$ & .576 & .523 & 494749636.613 \\
\hline
\end{tabular}

a. Predictors: (Constant), NETAS. 
Table 6 reveals that at $r=0.759$, hence there is very high and positive correlation between Net Assets (book value) and Total Assets of Consumer Goods Companies in Nigeria. The result is supported by the coefficient of determination $\left(\mathrm{R}^{2}=\right.$ $0.576)$ i.e. net assets explained 57.6 percent of the variation in Total Assets of consumer goods manufacturing companies in Nigeria during the period under study. It could be inferred that the book value of consumer goods firms determines the value of assets.

Table 7. Analysis of Variance on Net Assets and Assets of Consumer Goods companies in Nigeria.

\begin{tabular}{llllll}
\hline ANOVA $^{\mathrm{a}}$ & & & & & \\
\hline Model & & Sum of Squares & Df & Mean Square & p-value \\
\hline \multirow{3}{*}{1} & Regression & 2664909396335986700.000 & 1 & 2664909396335986700.000 \\
& Residual & 1958217623433512960.000 & 8 & 244777202929189120.000 \\
& Total & 4623127019769499600.000 & 9 & & $.011^{\mathrm{b}}$ \\
\end{tabular}

a. Dependent Variable: ASSETS.

b. Predictors: (Constant), NETAS

The $\mathrm{p}$-value in this analysis is 0.011 . Since $\mathrm{p}$-value $>$ we reject $\mathrm{H}_{0}$ and conclude that Net Assets (book value) have significant effect on the assets of consumer goods manufacturing companies in Nigeria.

Table 8. Regression Analysis of Net Asset value and Assets of consumer goods companies in Nigeria.

\begin{tabular}{|c|c|c|c|c|c|c|}
\hline \multicolumn{7}{|c|}{ Coefficients $^{\mathrm{a}}$} \\
\hline \multirow{2}{*}{ Model } & & \multicolumn{2}{|c|}{ Unstandardized Coefficients } & \multirow{2}{*}{$\begin{array}{l}\text { Standardized Coefficients } \\
\text { Beta }\end{array}$} & \multirow{2}{*}{$\mathrm{t}$} & \multirow{2}{*}{ p-value } \\
\hline & & B & Std. Error & & & \\
\hline \multirow{2}{*}{1} & (Constant) & 115736883.248 & 426034053.149 & & .272 & .793 \\
\hline & NETAS & 1.636 & .496 & .759 & 3.300 & .011 \\
\hline
\end{tabular}

a. Dependent Variable: ASSETS.

The regression model for this relationship is as follows:

$$
\text { ASSETS }=115,736,883.248+1.636(\text { NETAS })+0.759
$$

This implies that about N115.7bn was constantly contributed to Total Assets on annual basis throughout the period under study while the marginal change in the period is 1.636. The error term in this estimation is a negligible 0.757 .

\subsubsection{Analysis on Objective Three}

Restatement of the Objective

$\mathrm{H}_{0}$ : Depreciation does not have significant effect on assets of consumer goods manufacturing companies in Nigeria.

Decision Rule: Accept $\mathrm{H}_{0}$ if $\mathrm{p}$-value $>0.05$, otherwise reject.

Table 9. Correlation between depreciation and assets of consumer goods manufacturing companies in Nigeria.

\begin{tabular}{lllll}
\hline Model Summary & & & & \\
\hline Model & R & R Square & Adjusted R Square & Std. Error of the Estimate \\
\hline 1 & $.846^{\text {a }}$ & .717 & .681 & 404727832.755 \\
\hline
\end{tabular}

a. Predictors: (Constant), DEPR.

The coefficient of correlation in table 9 is $r=0.846$ while $\mathrm{R}^{2}=0.717$ or 71.7 percent. This implies that there is a very strong and positive correlation between depreciation and assets of consumer goods companies in Nigeria. It also means that depreciation is a strong determinant of the changes or variations in assets of consumer goods companies in Nigeria.

Table 10. Analysis of Variance on depreciation and assets of consumer goods manufacturing companies in Nigeria.

\begin{tabular}{llllll}
\hline ANOVA $^{\mathbf{a}}$ & & & & \\
\hline Model & & Sum of Squares & Df & Mean Square & p-value \\
\hline \multirow{3}{*}{1} & Regression & 3312690070916443600.000 & 1 & 3312690070916443600.000 \\
& Residual & 1310436948853056000.000 & 8 & 163804618606632000.000 \\
& Total & 4623127019769499600.000 & 9 & & \\
& & & & \\
\end{tabular}

a. Dependent Variable: ASSETS.

b. Predictors: (Constant), DEPR.

The analysis in table 10 reveals that $\mathrm{p}$-value $=0.002$. Since $\mathrm{p}$-value $<0.05$ we reject $\mathrm{H}_{0}$ and conclude that depreciation has significant effect on assets of consumer goods manufacturing companies in Nigeria. 
Table 11. Regression Analysis on depreciation and Assets of consumer goods manufacturing companies in Nigeria.

\begin{tabular}{|c|c|c|c|c|c|c|}
\hline \multicolumn{7}{|c|}{ Coefficients $^{\mathrm{a}}$} \\
\hline \multirow{2}{*}{ Model } & & \multicolumn{2}{|c|}{ Unstandardized Coefficients } & \multirow{2}{*}{$\begin{array}{l}\text { Standardized Coefficients } \\
\text { Beta }\end{array}$} & \multirow{2}{*}{$\mathbf{t}$} & \multirow{2}{*}{ p-value } \\
\hline & & B & Std. Error & & & \\
\hline & (Constant) & 222072823.823 & 296182062.853 & & .750 & .475 \\
\hline 1 & DEPR & 23.370 & 5.197 & .846 & 4.497 & .002 \\
\hline
\end{tabular}

a. Dependent Variable: ASSETS.

The regression model for this relationship is presented hereby, using the coefficients in table 11:

$$
\mathrm{ASSET}=222,072,823.823+23.370(\mathrm{DEPR})+5.197
$$

The analysis shows that there was a constant annual contribution of about $\$ 222.072$ to the assets of consumer goods firms in Nigeria within the period under investigation. There was also a significant annual marginal increase in assets as a result of the changes in depreciation of 23.370.

\section{Discussion of the Findings}

The study has been carried out using three specific objectives to ascertain the effect of fair value accounting on assets of consumer goods companies in Nigeria. The outcome of this analysis has also pointed to the fact that the three variables used as proxy for fair value proved to be significant factors in the assets of consumer goods firms in Nigeria for the period under study. The expectations of the researcher were fulfilled and it is now to serves as a premise for understanding the workings of the value of Consumer Goods Companies in Nigeria.

The findings were also in tandem with the resource-based theory which emphasizes the use of assets to compete in business. That is why the findings have also sealed the assumption that the more significant the variables are, the better the comparability of such firms to others based on their fair value and assets. Therefore, the objective of the study was realized fully and the appropriate benefits are inherent.

Summary of Findings

The findings from this study are summarized as follows:

1. Fair value accounting has significant effect on assets of consumer goods manufacturing companies in Nigeria.

2. Market value accounting has significant effect on assets of consumer goods manufacturing companies in Nigeria.

3. Depreciation has significant effect on assets of consumer goods manufacturing companies in Nigeria.

\section{Conclusion}

Fair value accounting has high and positive correlation with assets of a consumer goods firm. It spills over to rating or valuing the companies in the eyes of the public and investors market. It is only necessary to realize that investors always place value on the worth of a company and to ensure that they are paying fair value for what they want to acquire or pay for. The essence of this is to ensure that the value of assets are constantly maintained and sustained to attract better negotiation and competition in the market. This has been the concern of the researcher and to add to knowledge of users of accounting information and decision makers.

\section{Recommendations}

The study recommends that;

1. Managers of consumer goods companies in Nigeria should consolidate on improvement of fair value of firms through their assets management and appropriate policies.

2. Management of consumer goods companies should adopt the best practices that would raise the share prices and maintain higher book values of the firms.

3. Management should use depreciation as a source of replacement of old assetsthereby stabilizing the Networth of the firms. It is ill-advise to divert deductions from depreciation to other less important things thereby reducing the fair value of assets.

\section{References}

[1] Ubesie, M. C. (2018). Lecture notes on contemporary issues in accounting (ACC 916) - Unpublished, March 6, 2019.

[2] Accounting Tools (2018). Fair value accounting, available at https://www.accountingtools.com/articles/fair-valueaccounting.html, assessed on June 21, 2019.

[3] Balogun, E. O. (2015). Effect of fair value accounting on asset valuation in public limited companies (A study of petroleum companies in Nigeria), Journal of Accounting and Financial Management, 1 (5), 111-126.

[4] Chen, J. (2019). Market value, available at $\mathrm{https} / / \mathrm{www}$.investopedia.com>terms, assessed on Sept. 22, 2019.

[5] Kenton, W. (2019). Depreciation, available at https://www.investopedia.com/terms/d/depreciation.asp retrieved on September, 2019.

[6] Elfaki, A. A. A. \& Hammad, S. M. E. (2015). The impact of the application of fair value accounting on the quality of accounting information: An empirical study on a group of companies listed on the Khartoum Stock Exchange, International Journal of Academic Research in Accounting, Finance and Management Sciences, 5 (1), $148-160$.

[7] Barth, M. E. (1993). Fair value accounting: Evidence from investment securities and the market valuation of banks, The Accounting Review, 69 (2), 1-25. 
[8] Akwu, O. D. (2014). Examination of fair value measurement in determination of profitability of listed manufacturing firms in Nigeria. A dissertation presented to the department of accountancy, faculty of business administration, university of Nigeria, Enugu campus, in partial fulfillment of the requirements for the award of Master of Science (M. Sc) Degree in Accountancy, Sept., 2014.

[9] Ibrahim, M. (2016). Effect of earnings quality properties on share price of listed manufacturing firms in Nigeria, A thesis submitted to the School of Postgraduate Studies, Ahmadu Bello University, Zaria, in partial fulfillment of the requirements for the award of the Degree of Doctor of Philosophy (Ph. D) in Accounting and Finance.

[10] Okolie, A. O. (2014). Audit firm size and market price per share of quoted companies in Nigeria, International Journal of Business and Social Research (IJBSR), 4 (5), 100-117.

[11] Alade, M. E. (2018). Effect of international financial reporting standards adoption on value relevance of accounting information of Nigerian listed firms. A thesis submitted in partial fulfilment for the degree of Doctor of
Philosophy in Accounting in the Jomo Kenyatta University of Agriculture and Technology, Kenya.

[12] Kip, A. (2009). The effect of fair value accounting on the earnings response coefficient, AMaster thesis presented to Department of Accountancy, Faculty Economics and Business University of Amsterdam, Dec. 2009.

[13] Ezejiofor, R. A. (2018). Effect of IFRS on value relevance of Accounting Information: Evidence from quoted manufacturing firms in Nigeria, International Journal of Trend in Scientific Research and Development (IJTSRD), 2 (5), 2255-2201

[14] Ugwunta, D. O. \& Ugwuanyi, B. U. (2019). Accounting conservatism and performance of Nigerian consumer goods firms: An examination of the role of accruals, International Journal of Financial Research, 10 (1), 1-9.

[15] Okafor, T. G., Ogbuehi, A., \& Anene, N. O. (2017). IFRS Adoption and the Value Relevance of Accounting Information in Nigeria: An Empirical Study, Journal of Modern Accounting and Auditing, 13 (10), 421-434, doi: 10.17265/1548-6583/2017.10.001. 